\title{
A Semi-Quantitative Risk Assessment and Management Strategies on COVID-19 Infection to Outpatient Health Care Workers in the Post- Pandemic Period
}

Risk Management and Healthcare Policy

\section{Yuncong Wang \\ Lihong Wang \\ Xia Zhao \\ Jingli Zhang \\ Wenhui Ma \\ Huijie Zhao \\ Xu Han}

Hospital Infection Management Division, Xuan Wu Hospital Capital Medical University, Beijing, People's Republic of China
Correspondence: Lihong Wang

Director of Division of Hospital Infection Management Division, Xuan Wu Hospital Capital Medical University, No. 45

ChangChun Street, Xicheng District,

Beijing, 100053, People's Republic of

China

Tel +8601083198602

Email186I8247I82@I63.com
Background: In the pandemic of COVID-19, due to asymptomatic patients and high personnel fluidity in outpatient clinics, health care workers (HCWs) in outpatients were facing severe threat from infection. There is an urgent need for a risk assessment to recognize and prevent infection risks.

Purpose: To establish a semi-quantitative risk assessment model on COVID-19 infections for HCWs in outpatient departments, and apply it to practices. Further to provide infection risk management strategies to reduce infection threats in the post-pandemic of COVID-19.

Methods: We used the method of Brainstorm, Literature study and Analytic Hierarchy Process (AHP) for risk factors selection and model construction, we also created corresponding indicators for each risk factors, in order to collect data in assessment practice.

Results: Eighteen risk factors were recognized and selected for model construction, by scatter plot, these risk factors had been classified into four parts, spanned the scopes of diagnosis and treatment, environment, personal protection and emergency handling, with specific management suggestions provided. In the practice, outpatient clinics were divided into three risk levels, 5 clinics in high risk level, 9 in medium risk level and 11 in low risk level.

Conclusion: A proper comprehensive risk assessment model for COVID-19 infections has been successfully established. With the model, the ability to COVID-19 prevention in outpatients can be easily evaluated. The strategies on disinfection, surveillance and personal protection were also valuable references in the post-pandemic of COVID-19.

Keywords: COVID-19, health care workers; HCWs, outpatient, risk assessment

COVID-19 first emerged in the city of Wuhan, China, and spread rapidly throughout the country and the world. The WHO declared a global health emergency on 31 January 2020, due to the severe spread of COVID-19.

COVID-19 has more powerful pathogenicity and transmissibility than SARS and MERS. ${ }^{1}$ The main transmission method of COVID-19 were droplets and contact, ${ }^{2}$ which can be confirmed within a very short exposure time in the absence of personal protective equipment (PPE) like masks. ${ }^{3}$

During the pandemic of COVID-19, the health care workers (HCWs) in outpatient clinics faced high risks of hospital-related transmission of COVID-19., ${ }^{4,5}$ 
The severe challenges of COVID-19 control and prevention among HCWs came from three aspects. The first one was the weakness and insufficiency of surveillance ability, infrastructure upgrade, and resource supplement; ${ }^{6}$ The second one was the difficulty of identification to COVID-19 infected patients in outpatient; ${ }^{7}$ The third one was HCWs themselves, they were vulnerable to both common and novel respiratory pathogens, ${ }^{8,9}$ and the nonnormative behavior and manipulations of HCWs played the role of vehicles for transmission of COVID-19, which may cause more serious damage, and even nosocomial outbreaks in outpatient settings. ${ }^{10}$

In the post-pandemic of COVID-19, like the condition of China, the infection risk is lower than the early phase of the pandemic period. But the HCWs are still facing uncertain infection risks and need solid protection, due to the asymptomatic or pre-symptomatic patients. ${ }^{11}$ On the other hand, the large financial cost, the fragile supplement chain, as well as the overuse and misuse all limited the application of PPE. ${ }^{12,13}$ In order to solve the problem and provide more efficient protection to HCWs, it was urgent to perform risk assessment on COVID-19 infection among HCWs and provide leveled infection prevention strategies.

Risk assessment was first introduced to enterprise management by French managerialist Henri Fayol. China started the risk assessment in nosocomial infection control and prevention since $2005 .{ }^{14}$ In these years, some research focused on the risk assessment in outpatient clinics in China. Most research focused on the department of Stomatology, the Department of Ophthalmology and the department of Otolaryngology, ${ }^{15}$ but few of them give attention on the risk level and risk control strategy of the whole outpatient setting.

The aim of our study was to develop a risk assessment model to grade COVID-19 infection risk levels of outpatient clinics, and provide proper management strategy to meet the requirement of infection control and prevention to COVID-19 in outpatient.

\section{Method}

\section{Study Design}

We conducted a cross-sectional study to recognize the COVID-19 infection risk of HCWs in outpatients, and rank outpatient clinics into different risk levels to provide specific infection prevention strategies.

This study was conducted in two steps. We first attempted to construct a risk assessment model. Risk factors were selected according to reference research or expert consultations, then we invited experts to identify the risk weight by Analytic Hierarchy Process (AHP), a series of pairwise comparisons were used to determine the relative importance of the selected risk factors. Secondly, we created indicators for each risk factors to collect data for risk scores calculation and statistical analysis. Finally, all outpatient clinics were divide into different risk levels by the sum of risk scores, the strategies on infection control and prevention were also provided.

\section{Selection of Risk Factors}

In this research, a expert panel with excellent theoretical knowledge and practical skills was established for consultation, including 13 clinical physicians, 5 nurses, 7 administrators on nosocomial infection, 2 administrators in outpatient management and 2 administrators in nursing management.

Several widely used electronic databases, like PubMed, $\mathrm{NCBI}($ Chinese) and $\mathrm{CNKI}($ Chinese), were critically reviewed with keywords including "COVID-19," "outpatient infection control," "infection control," "health care workers," "respiratory tract infection," "respiratory infection," "risk," "risk assessment," and "risk factor." The articles searching and summarizing was conducted by two research assistants of expert panel, then a pool of articles was established for selection.

The article selection was conducted by an expert panel. The exclusion criteria were: 1) Articles without abstract or was unavailable for download; 2) Article types were: conference article, letters, case report and overview (not systematic review); 3) Articles' scope were associated with psychology, clinical trail, clinical therapy; and 4) Articles with no explicit risk factors recommended, or with unreliable data analysis. Finally, we searched 33 articles in Chinese and 63 articles in English, and a total of 35 articles were included for further study after selection.

From the selected articles, a total of 33 risk factors were extracted. The selection of risk factors was conducted by the expert panel using questionnaire consultation and team discussion. ${ }^{16,17}$ The inclusion criteria were: 1) Risk factors were highly recommended in selected articles or documents published by the National Health Commission of the People's Republic of China; 2) Risk factors could be easily observed in practice; and 3) Risk factors should have accurate representativeness on the risk of COVID-19 infections to HCWs. 
According to these three criteria, experts selected high quality risk factors, and classified them to construct a risk assessment model.

\section{Evaluation of Risk Factors}

We attempted to use a scatter plot to evaluate the selected risk factors. We collected the data of "grade of risk probability$(\mathrm{P})$ " and "severity of risk consequences(C)" from expert panel through questionnaires, and constructed a scatter plot with $\mathrm{P}$ as $\mathrm{X}$ axles and $\mathrm{C}$ as $\mathrm{Y}$ axles. Then we used the transparency of spots to represented $\mathrm{P}$ grade and the size to represented $\mathrm{C}$ grade. We also drew two crossed lines of $\mathrm{X}=$ average $(\mathrm{P})$ and $\mathrm{Y}=$ average $(\mathrm{C})$ to divide the scatter plot into four quadrants to formulate proper management strategy.

\section{Analytic Hierarchy Process (AHP)}

All selected risk factors were classified into four categories according to content and characters. In categories, each risk factors was compared with other ones, according to its relative contribution to the risk of respiratory infections on HCWs in outpatient. A score scale of 1-9 points was conducted for the pairwise comparison, in which score 1 stands for equal importance, and scores of 3, 5, 7, and 9 denoted weakly, strongly, very strongly, and absolutely more important, scores $2,4,6$, and 8 were used when slight differences existed between criteria. ${ }^{18,19}$

From the expert panel, we invited 19 experts who had the experience of nosocomial infection control management to participate questionnaires interviews to conduct the AHP process. Consistency index (CI) and consistency ratio $(\mathrm{CR})$ were calculated to evaluate the consistency of the pairwise comparisons. The CI and CR were generally considered to be lager than 0.10 to guarantee a acceptable comparisons quality. ${ }^{20}$

All calculation process were done by the software of Yaahp (Yuanjuecue Software Technology Co., Ltd). The final weighting of risk indicators were the average of AHP process result from 19 experts.

\section{The Risk Assessment Practice}

The assessment practice was conducted during Jun 16 to July 3, 2020, in the outpatient of Xuanwu Hospital Capital Medical University, which was built in 1958, renowned for neuroscience and geriatrics. The annual number of outpatient visits of Xuanwu Hospital reached more than 2.9 million in 2019. Xuanwu Hospital is the chairman of the hospital infection control professional committee of Beijing Preventive Medical Association and Beijing Hospital Association.
On the basis of assessment model we established, the expert panel created indicators for each risk factor to perform semi-quantitative risk assessment practice. The indicators included three types: 1) Single Selection (SS), several graded risk levels were presetted by expert panel, assessor select the matched risk level according to clinics' characters and reality. The risk score of this indicator is the score of this selection; 2) Multiple Selection (MS), several equal-level risk possibilities were presetted, assessor select all matched ones according to clinics' characters and fact. The risk score of this indicator is the sum of scores of all selections; and 3) Normalized Ratio (NR), a special ratio was created by the expert panel to reflect risk severity.

With these indicators, the data of all risk factors was collected by field observation and Outpatient Management Database searching.

\section{Statistical Analysis}

A Non-parametric statistical method Weighted Rank Sum Ratio (WRSR) was conducted for risk level evaluation. After data collection, WRSR value was calculated in each clinic, and probability unit Probit was used to express the distribution of WRSR to divide outpatient clinics into different risk levels.

In WRSR process, a linear equation was constructed with WRSR values as independent variables and Probit as dependent variables. The risk level was divided by the Probit equal to 5.0 and 6.0. The WRSR in different levels should meet the requirement of homogeneity of variances and significant difference. ${ }^{21}$

\section{Result}

\section{The Risk Assessment Model}

A total of 18 risk factors were finally brought into the risk assessment model on COVID-19 infections of outpatient HCWs, and divided into four constructs (Table 1). The information of supporting articles to risk factors were showed in Table 2. In this model, "Diagnosis and treatment" had 7 risk factors; "Environment and layout" had 5 risk factors; "Personal protection" had 5 risk factors and "Emergency handling" had 1 risk factor. The risk factor "Close respiratory tract examination (with aerosol generation possibility)" had got the highest weight (0.1241).

\section{The Indicators for Risk Factors}

All indicators were showed in Table 3. The applicable conditions were: 1) indicators were not available in 
Table I The Risk Assessment Model on Respiratory Infection of HCWs in Outpatient Settings

\begin{tabular}{|c|c|c|c|}
\hline Risk Categories & Weight & Risk Factors & Weight \\
\hline \multirow[t]{7}{*}{ A. Diagnosis and treatment process } & \multirow[t]{7}{*}{0.2630} & a. Density of outpatient patients & 0.0361 \\
\hline & & b. Critical level of primary disease & 0.0912 \\
\hline & & c. Average length of time for diagnosis and treatment & 0.0230 \\
\hline & & d. Patients' correlation with respiratory tract disease & 0.0384 \\
\hline & & e. Close respiratory tract examination (with aerosol generation possibility) & 0.1241 \\
\hline & & f. Normativity of pre-examination and triage & 0.0646 \\
\hline & & g. Compliance of hand hygiene & 0.0605 \\
\hline \multirow[t]{5}{*}{ B. Environment and layout } & \multirow[t]{5}{*}{0.1874} & h. Normativity of air cleaning and ventilation & 0.0407 \\
\hline & & i. Normativity of environmental cleaning and disinfection & 0.0339 \\
\hline & & j. Usable floor area of patients waiting zone & 0.0243 \\
\hline & & k. The one-patient limitation for one consulting room & 0.0404 \\
\hline & & I. Results of environmental cleaning and disinfection & 0.0464 \\
\hline \multirow[t]{5}{*}{ C. Personal protection } & \multirow[t]{5}{*}{0.3818} & m. Participation rate of training on infection control and prevention & 0.0221 \\
\hline & & n. Qualification rate of training on infection control and prevention & 0.0253 \\
\hline & & o. Proportion of HCWs wearing correct mask & 0.1207 \\
\hline & & p. Proportion of outpatient patients wearing correct mask & 0.1077 \\
\hline & & q. Proportion of HCWs receiving influenza vaccine & 0.0409 \\
\hline D. Emergency handling & 0.1678 & r. The ability of emergency handling on respiratory infectious exposure & 0.1137 \\
\hline
\end{tabular}

Fever Clinic; 2) all the indicators based on observation should conducted in an identical week; 3) the standard of pre-examination and triage should at least include "checking body temperature" and "inquiring about fever history"; and 4) the consulting room with nonstandard air ventilation was the room without windows, mechanical ventilation nor air-cleaning equipment.

\section{The Classification and Evaluation of Risk Factors}

The average values of $\mathrm{P}$ and $\mathrm{C}$ were 2.5 and 3.0 respectively, we use them to divide 18 risk factors into four quadrants (Figure 1).

The top right quadrant was the "High Probability and High Consequences (HPHC) risk factors" (e, g, p, and q), they pose the highest threat to HCWs' COVID19 infections, and play a critical role in infection control.

The top left quadrant was the "Low Probability and High Consequences (LPHC) risk factors" (b, f, h, i, l, o, and $r$ ), they may not be frequently observed in outpatient settings, but can pose a severe threat to HCWs' COVID-19 infection when they existed.

The lower right quadrant was the "High Probability and Low Consequences (HPLC) risk factors" (a, c, d and j), they had high probability to be observed in outpatient settings but made limited contributions to HCWs' COVID-19 infection.

The lower left quadrant was the "Low Probability and Low Consequences (LPLC) risk factors" ( $k, m$ and $n$ ), they had both low level in probability and threat to HCWs' COVID-19 infection.

\section{The Risk Level of COVID-19 Infections of Outpatient Clinics}

The result of statistical analysis showed significant correlation between WRSR and Probit $(\mathrm{r}=0.987, \mathrm{p}=0.058)$, the linear equation was WRSR $=0.366+0.034$ Probit.

The value range of WRSR of high risk level was from 0.5824 to 0.6340 , including: Emergency Clinic, 
Table 2 Detailed Characteristics of Articles Included in the Selected Risk Factors

\begin{tabular}{|c|c|c|c|c|}
\hline $\begin{array}{l}\text { Risk } \\
\text { Factors }\end{array}$ & Study Name & $\begin{array}{l}\text { Methodological } \\
\text { Design }\end{array}$ & Research Conclusion & $\begin{array}{l}\text { Odds Ratio } \\
(95 \% \mathrm{CI})\end{array}$ \\
\hline $\mathrm{a}$ & Mehmet Aydin $(2020)^{35}$ & $\begin{array}{l}\text { Comparative } \\
\text { study }\end{array}$ & $\begin{array}{l}\text { The horizontal distance travelled by droplet was } 1.7 \mathrm{~m} \text { due to } \\
\text { breathing or talking and } 2.94 \mathrm{~m} \text { due to sneezing or coughing. }\end{array}$ & NA \\
\hline b & Fu-Der Wang $(2007)^{36}$ & $\begin{array}{l}\text { Cross-sectional } \\
\text { serosurvey }\end{array}$ & $\begin{array}{l}\text { Risk of contracting SARS for HCWs in the emergency room } \\
\text { was much greater than in the ordinary ward. }\end{array}$ & $25.94(7.07-95.14)$ \\
\hline c & $\operatorname{Ran} L(2020)^{37}$ & $\begin{array}{l}\text { Retrospective } \\
\text { cohort study }\end{array}$ & $\begin{array}{l}\text { Cumulative proportion of infection-free HCWs would be } \\
\text { decreased with daily workhour. }\end{array}$ & NA \\
\hline d & $\begin{array}{l}\text { Charlotte V Hobbs } \\
\qquad(2020)^{38}\end{array}$ & $\begin{array}{l}\text { Case-control } \\
\text { study }\end{array}$ & $\begin{array}{l}\text { Infected individuals were more likely to have had close } \\
\text { contact with a person with known COVID-19. }\end{array}$ & $3.2(2.0-5.0)$ \\
\hline e & C R Macintyre $(20 \mid 4)^{33}$ & Prospective study & $\begin{array}{l}\text { HCWs who performed a HRP were at significantly higher } \\
\text { risk. }\end{array}$ & $2.9(1.42-5.87)$ \\
\hline$f$ & Qiaoxia Wang $(2020)^{39}$ & $\begin{array}{l}\text { Cross-sectional } \\
\text { survey }\end{array}$ & $\begin{array}{l}\text { The triage procedure effectively screened the patients and } \\
\text { identified the high-risk population. }\end{array}$ & NA \\
\hline$g$ & Yen MY $(2011)^{40}$ & $\begin{array}{l}\text { Retrospective } \\
\text { study }\end{array}$ & $\begin{array}{l}\text { Suboptimal handwashing before or after patient contact is } \\
\text { a risk factor of COVID-19 infection. }\end{array}$ & $\begin{array}{l}3.10(1.43-6.73) \\
2.82(1.11-7.18)\end{array}$ \\
\hline h & $\begin{array}{l}\text { Manoj Kumar Satheesan } \\
\qquad(2020)^{41}\end{array}$ & $\begin{array}{l}\text { Comparative } \\
\text { study }\end{array}$ & Air change is highly recommended to lower infection risk & NA \\
\hline i & $\begin{array}{l}\text { Vincent Chi-Chung Cheng } \\
\qquad(2020)^{42}\end{array}$ & $\begin{array}{l}\text { Cross-sectional } \\
\text { survey }\end{array}$ & $\begin{array}{l}5.0 \% \text { (19/337)environmental samples close to COVID-19 } \\
\text { patients were positive by RT-PCR assay. }\end{array}$ & NA \\
\hline j & $\begin{array}{c}\text { World Health } \\
\text { Organization }(2018)^{43}\end{array}$ & Official guideline & Acquiring respiratory diseases was associated with crowding. & NA \\
\hline K & Mehmet Aydin (2020) ${ }^{35}$ & $\begin{array}{l}\text { Comparative } \\
\text { study }\end{array}$ & $\begin{array}{l}\text { The horizontal distance travelled by droplet was } 1.7 \mathrm{~m} \text { due to } \\
\text { breathing or talking. }\end{array}$ & NA \\
\hline I & Tianxiang $(2020)^{44}$ & $\begin{array}{l}\text { Cross-sectional } \\
\text { study }\end{array}$ & $\begin{array}{l}\text { Routine disinfection procedures were effective in reducing } \\
\text { the potential risk of healthcare associated infection. }\end{array}$ & NA \\
\hline $\mathrm{m}$ & Xiaodong Guo $(2020)^{45}$ & $\begin{array}{l}\text { Cross-sectional } \\
\text { study }\end{array}$ & $\begin{array}{l}\text { Participation in training on prevention measures have } \\
\text { a protective effect against COVID-19. }\end{array}$ & NA \\
\hline $\mathrm{n}$ & $\begin{array}{l}\text { Shivalingesh Krishnappa } \\
\text { Kamate }(2020)^{46}\end{array}$ & $\begin{array}{l}\text { Cross-sectional } \\
\text { study }\end{array}$ & $\begin{array}{l}\text { Good knowledge and practice scores were important to } \\
\text { combat COVID-19. }\end{array}$ & NA \\
\hline ० & $\begin{array}{c}\text { World Health } \\
\text { Organization }(2014)^{47}\end{array}$ & Official guideline & $\begin{array}{l}\text { Masks were recommended to protect healthcare workers } \\
(\mathrm{HCW}) \text { from seasonal influenza. }\end{array}$ & NA \\
\hline$P$ & Vittoria Offeddu $(2017)^{48}$ & Systematic Review & Masks provide a protective effect against SARS. & $0.13(0.03-0.62)$ \\
\hline q & $\begin{array}{l}\text { Vittorio Demicheli } \\
\qquad(2018)^{49}\end{array}$ & Systematic Review & $\begin{array}{l}\text { Vaccines probably reduce influenza in healthy adults from } \\
2.3 \% \text { without vaccination to } 0.9 \% \text {. }\end{array}$ & $0.4 \mathrm{I}(0.36-0.47)$ \\
\hline $\mathrm{r}$ & Zixing Huang $(2020)^{50}$ & Prospective study & $\begin{array}{l}\text { Emergency strategic planning can help protect patients and } \\
\text { staff against a highly infectious disease. }\end{array}$ & NA \\
\hline
\end{tabular}

Paediatrics Clinic, Stomatology Clinic, E.N.T.Clinic and Pneumology Clinic. The medium risk level was from 0.5424 to 0.5718 , including 9 departments. The low risk level was from 0.4771 to 0.5305 , including 11 departments (Table 4). The WRSR in three levels meet the requirement of homogeneity of variances (Levene $=0.878, \mathrm{P}=0.430$ ) and significant difference $(\mathrm{F}=35.614, \mathrm{P} \leq 0.001)$. 
Table 3 The Semi-Quantitative Scoring Indicators

\begin{tabular}{|c|c|c|c|c|c|c|c|}
\hline $\begin{array}{l}\text { Risk } \\
\text { Categories }\end{array}$ & Risk Factors & Type & A (I Point) & B (2 Point) & C (3 Point) & D (4 Point) & E (5 Point) \\
\hline \multirow{7}{*}{$\begin{array}{l}\text { A. Diagnosis } \\
\text { and treatment } \\
\text { process }\end{array}$} & a. Density of outpatient patients & RM & \multicolumn{5}{|c|}{$\begin{array}{l}\text { The number of outpatient visitors in a week/the number of physicians available for } \\
\text { outpatient health care in a week }\end{array}$} \\
\hline & b. Critical level of primary disease & SS & $\begin{array}{c}\text { Stable } \\
\text { condition }\end{array}$ & & & & $\begin{array}{l}\text { Critical } \\
\text { condition } \\
\text { without } \\
\text { infection } \\
\text { triage }\end{array}$ \\
\hline & $\begin{array}{l}\text { c. Average length of time for } \\
\text { diagnosis and treatment }\end{array}$ & RM & \multicolumn{5}{|c|}{$\begin{array}{l}\text { The total medical working hours of outpatient physicians in a week/the number of } \\
\text { outpatient patients in a week }\end{array}$} \\
\hline & $\begin{array}{l}\text { d. Patients may associated with } \\
\text { respiratory tract disease }\end{array}$ & SS & Not involved & & $\begin{array}{l}\text { Can not be } \\
\text { excluded }\end{array}$ & & $\begin{array}{l}\text { In main scope } \\
\text { of treatment }\end{array}$ \\
\hline & $\begin{array}{l}\text { e. Close respiratory tract } \\
\text { examination (with aerosol } \\
\text { generation possibility) }\end{array}$ & SS & Not involved & $\begin{array}{l}\text { Respiratory } \\
\text { tract closed, } \\
\text { close range, } \\
\text { over } 10 \mathrm{~min}\end{array}$ & $\begin{array}{l}\text { Respiratory } \\
\text { tract open, } \\
\text { close range, } \\
\text { less than } 10 \\
\text { min }\end{array}$ & $\begin{array}{l}\text { Respiratory } \\
\text { tract open, } \\
\text { close range, } \\
\text { over } 10 \mathrm{~min}\end{array}$ & $\begin{array}{l}\text { Respiratory } \\
\text { tract open, } \\
\text { close range, } \\
\text { aerosol } \\
\text { generating }\end{array}$ \\
\hline & $\begin{array}{l}\text { f. Normativity of pre-examination } \\
\text { and triage }\end{array}$ & RM & \multicolumn{5}{|c|}{$\begin{array}{l}\text { Number of normative pre-examination and triage/number of all pre-examination } \\
\text { and triage in observation }\end{array}$} \\
\hline & g. Compliance of hand hygiene & RM & \multicolumn{5}{|c|}{ Number of hand hygiene/all hand hygiene opportunity in observation } \\
\hline \multirow[t]{5}{*}{$\begin{array}{l}\text { B. Environment } \\
\text { and layout }\end{array}$} & $\begin{array}{l}\text { h. Normativity of air cleaning and } \\
\text { ventilation }\end{array}$ & RM & \multicolumn{5}{|c|}{$\begin{array}{l}\text { Number of consulting room with air ventilation/number of all available consulting } \\
\text { room }\end{array}$} \\
\hline & $\begin{array}{l}\text { i. Normativity of environmental } \\
\text { cleaning and disinfection }\end{array}$ & MS & $\begin{array}{l}\text { Low } \\
\text { frequency }\end{array}$ & $\begin{array}{l}\text { Incorrect } \\
\text { method }\end{array}$ & $\begin{array}{l}\text { Sanitizer } \\
\text { production } \\
\text { expired }\end{array}$ & $\begin{array}{c}\text { Incorrect } \\
\text { concentration }\end{array}$ & $\begin{array}{l}\text { Insufficient } \\
\text { human } \\
\text { resources }\end{array}$ \\
\hline & $\begin{array}{l}\text { j. Usable floor area of patients } \\
\text { waiting zone }\end{array}$ & RM & \multicolumn{5}{|c|}{ Usable area of waiting zone/the number of outpatient visitors in a week } \\
\hline & $\begin{array}{l}\text { K. One consulting room confine } \\
\text { one patient receiving health care }\end{array}$ & RM & \multicolumn{5}{|c|}{$\begin{array}{l}\text { Number of qualified available consultation room/number of all available } \\
\text { consultation rooms }\end{array}$} \\
\hline & $\begin{array}{l}\text { I. Results of Environmental } \\
\text { cleaning and disinfection }\end{array}$ & SS & Excellent & Fine & Acceptable & Average level & Poor \\
\hline \multirow[t]{5}{*}{$\begin{array}{l}\text { C. Personal } \\
\text { protection }\end{array}$} & $\begin{array}{l}\text { m. Participation rate of training } \\
\text { on infection control and } \\
\text { prevention }\end{array}$ & RM & \multicolumn{5}{|c|}{ The number of participants of examination/the number of all HCWs in clinics } \\
\hline & $\begin{array}{l}\text { n. Qualification rate of training on } \\
\text { infection control and prevention }\end{array}$ & RM & \multicolumn{5}{|c|}{$\begin{array}{l}\text { The number of qualification HCWs in examination/the number of all HCWs } \\
\text { participating examination }\end{array}$} \\
\hline & $\begin{array}{l}\text { o. Proportion of HCWs wearing } \\
\text { correct mask }\end{array}$ & RM & \multicolumn{5}{|c|}{$\begin{array}{l}\text { The number of HCWs with correct mask wearing/the number of physician in } \\
\text { observation }\end{array}$} \\
\hline & $\begin{array}{l}\text { p. Proportion of outpatient } \\
\text { patients wearing correct mask }\end{array}$ & RM & \multicolumn{5}{|c|}{ The number of outpatient patients with correct mask wearing } \\
\hline & $\begin{array}{l}\text { q. Proportion of HCWs receiving } \\
\text { influenza vaccine }\end{array}$ & RM & \multicolumn{5}{|c|}{$\begin{array}{l}\text { The number of HCWs with influenza vaccine inoculated/the total number of } \\
\qquad \mathrm{HCWs} \text { in outpatient clinics }\end{array}$} \\
\hline
\end{tabular}

(Continued) 
Table 3 (Continued).

\begin{tabular}{|l|l|c|c|c|c|c|c|}
\hline $\begin{array}{l}\text { Risk } \\
\text { Categories }\end{array}$ & Risk Factors & Type & A (I Point) & B (2 Point) & C (3 Point) & D (4 Point) & E (5 Point) \\
\hline $\begin{array}{l}\text { D. Emergency } \\
\text { handling }\end{array}$ & $\begin{array}{l}\text { r. The ability of emergency } \\
\text { handling on respiratory infectious } \\
\text { exposure }\end{array}$ & MS & $\begin{array}{c}\text { Unfamiliarity } \\
\text { with PPE }\end{array}$ & $\begin{array}{c}\text { Unfamiliarity } \\
\text { with } \\
\text { emergency } \\
\text { protocol }\end{array}$ & $\begin{array}{c}\text { Unfamiliarity } \\
\text { with report } \\
\text { protocol }\end{array}$ & $\begin{array}{c}\text { Unfamiliarity } \\
\text { with terminal } \\
\text { disinfection }\end{array}$ & $\begin{array}{c}\text { Unfamiliarity } \\
\text { with triage for } \\
\text { fever patients }\end{array}$ \\
\hline
\end{tabular}

\section{Discussion}

\section{The Selection of Risk Factors and Statistical Indicators}

We used the method of Brainstorm and literature extraction to construct a primary risk factors pool for selection, and 18 risk factors had finally passed the selection process. We paid considerable attention to the risk factors with the ability to represent the reality of outpatient infection control, and may contradict other research.

For instance, the research of Van Buynder ${ }^{22}$ and Jiang $\mathrm{Wu}^{23}$ suggested that both the fact of HCWs owning a car and the number of HCWs' family members with respiratory infections contributed to the infection risk. On the contrary, the expert panel of our research believed that in the reality of China, considering the degree of crowding on all types of transport, taking a public bus for daily commutes provides more threat to HCWs' infection. For the second research, the expert panel came to an agreement that the aim of our research should focus on the infections happening in outpatient settings. So these two research conclusions werenot brought into our risk pool.

We regarded the risk posed by COVID-19 infections in the process of group consultation and in the collection of medical waste as a tiny probability, but could be easily avoided, which means their representativeness was relatively low, so we finally excluded the.

Some research reported the method of counting the use of alcohol-based hand rub (AHR) to represent the compliance with hand hygiene. According to the fact of outpatient settings in China, a number of outpatient clinics used hand washing with flowing water instead of AHR, so we used the method of observation to score most risk factors in the categories of "Environment and layout" and "Personal protection," such as "Compliance of hand hygiene." 24

\section{Management Strategies for Risk Factors}

Risk assessment is a scientific method for effectively improving HAI management. The implementation of

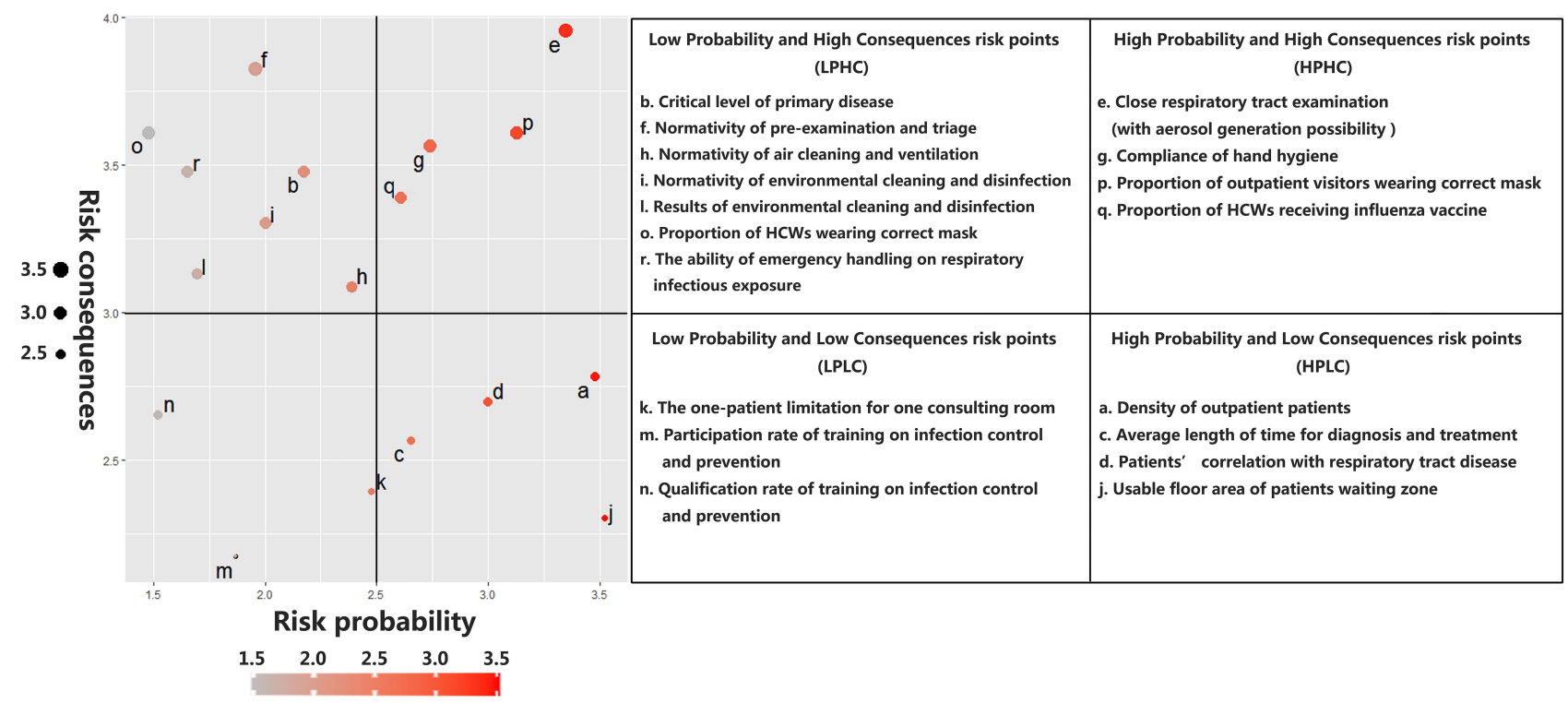

Figure I The scatter plot of risk factors and the four management quadrants. 
Table 4 The Risk Level of COVID-19 Infections of Outpatient Clinics

\begin{tabular}{|c|c|c|c|c|}
\hline Clinics & WRSR & Probit & WRSR & $\begin{array}{l}\text { Risk } \\
\text { Level }\end{array}$ \\
\hline Emergency Clinic & 0.6340 & 7.43 & 0.618 & High \\
\hline Paediatrics Clinic & 0.5859 & 6.85 & 0.599 & High \\
\hline Stomatology Clinic & 0.5844 & 6.51 & 0.587 & High \\
\hline E.N.T.Clinic & 0.5839 & 6.27 & 0.579 & High \\
\hline Pneumology Clinic & 0.5824 & 6.09 & 0.573 & High \\
\hline $\begin{array}{l}\text { Traditional Chinese } \\
\text { Medicine Clinic }\end{array}$ & 0.5718 & 5.94 & 0.568 & Medium \\
\hline Rehabilitation Clinic & 0.5589 & 5.81 & 0.563 & Medium \\
\hline Neurosurgery Clinic & 0.5582 & 5.68 & 0.559 & Medium \\
\hline Thoracic Surgery Clinic & 0.5562 & 5.57 & 0.555 & Medium \\
\hline Hematology Clinic & 0.5547 & 5.46 & 0.552 & Medium \\
\hline General Surgery Clinic & 0.5464 & 5.35 & 0.548 & Medium \\
\hline Vascular Surgery Clinic & 0.5461 & 5.25 & 0.545 & Medium \\
\hline Osteology Clinic & 0.5457 & 5.15 & $0.54 I$ & Medium \\
\hline Ophthalmology Clinic & 0.5424 & 5.05 & 0.538 & Medium \\
\hline Endocrinology Clinic & 0.5305 & 4.95 & 0.534 & Low \\
\hline Gastroenterology Clinic & 0.5304 & 4.85 & 0.531 & Low \\
\hline Neurology Clinic & 0.5268 & 4.74 & 0.527 & Low \\
\hline Cardiology Clinic & 0.5254 & 4.63 & 0.523 & Low \\
\hline Dermatology Clinic & 0.5247 & 4.52 & 0.520 & Low \\
\hline $\begin{array}{l}\text { Functional Neurosurgery } \\
\text { Clinic }\end{array}$ & 0.5205 & 4.39 & 0.515 & Low \\
\hline Pain Treatment Clinic & 0.5170 & 4.26 & $0.5 \mathrm{II}$ & Low \\
\hline Urology Clinic & 0.5156 & 4.11 & 0.506 & Low \\
\hline Nephrology Clinic & 0.5002 & 3.93 & 0.499 & Low \\
\hline $\begin{array}{l}\text { Rheumatology and } \\
\text { Immunology Clinic }\end{array}$ & 0.4876 & 3.69 & 0.492 & Low \\
\hline $\begin{array}{l}\text { Obstetrics and } \\
\text { Gynecology Clinic }\end{array}$ & $0.477 \mid$ & 3.35 & 0.480 & Low \\
\hline
\end{tabular}

proper and targeted management, based on risk assessment, may achieve acceptable results. ${ }^{21,25}$

In the pandemic of COVID-19, we suggested targeted management for risk factors in different quadrants. For the risk factors of HPHC, which played a critical role in the HCWs' respiratory infections. We suggestimplementing top level management, including tight surveillance, severe punishment, and emergency handling drill, to improve the consciousness of COVID-19 infection prevention. For the risk factors of LPHC, we suggested to apply Work Log, Standard Operating Procedure (SOP) to institutionalize and standardize the daily risk prevention measures, such as disinfection, ventilation, and training. For the HPLC, we should pay attention to reducing the risk probability of controlling the risk threat. The effective measurements may include optimization of diagnosis and treatment processes, optimization of environment cleaning and layout, and supplement of management stipulation. For the risk factors of LPLC, because of the low level of risk probability and consequence, we suggestproviding low level attention and strength to these risk factors, and include the management of LPLC into the list of regular surveillance.

Besides the conventional measures used in infection control and prevention, some novel techniques have been reported to apply in the improvement of infection control and prevention. The Unannounced Standardized Patient (USP) is the method that using highly trained actors to observe and measure the quality of medical practice and health-care associations with standard checklist. ${ }^{26,27}$ The USP is considered as a gold standard for evaluating healthcare providers in many domains, and has the ability to reduce Hawthorne effect to avoid inherent observational bias. ${ }^{28-30}$ So, if possible, the USP might be a good choice for surveillance and management of HPLC risk factors.

Several techniques have gone beyond training and lectures, such as reminder sounds, practical simulations, videos surveillance, and audiovisual media, which showed more effectiveness in the improvement of selfmanagement and compliance. ${ }^{31}$ We considered that these methods might be the proper approach for the management of LPLC risk factors.

\section{The Analysis of Risk Level of Outpatient Clinics}

In high risk level, the emergency clinic took first place. In the medium level, the rehabilitation treatment clinic, the ophthalmology clinic and the traditional Chinese medicine clinic took the top three.

The main reason for the ranking, to a large extent, was their high risk scores in the high weighted risk factors like "Close respiratory tract examination (with aerosol generation possibility)," "Diagnosis and treatment were associated with respiratory tract disease" and "the critical 
level of primary disease." These risk factors played key role in the respiratory infection of $\mathrm{HCWs},{ }^{32,33}$ and also constituted part of the risk characters of these clinics, so the list of high level risk clinics may probably maintain stabilization in long-term, especially in the pandemic of COVID-19.

What we should notice was that the medium risk level clinics may have more uncertainty, because most of the scores of risk factors in the categories of "Environment and layout" and "Personal protection" were collected by observation or calculation, they reflected the current outcomes and consciousness of infection prevention, and also made more contribution to the ranking of medium level. So the staff of nosocomial infection control departments should pay more attentionto improve the clinics at the medium risk level. Methods like personnel training, targeted interventions, clinical supervision, and the novel techniques discussed above could be taken into consideration.

\section{Suggestion for Personal Protective Equipment (PPE)}

In the COVID-19 pandemic, we suggested to conduct hierarchical PPE to prevent different risk level respiratory infection of HCWs. ${ }^{34}$ The basic PPE should include surgical mask, medical uniform, and medical caps and should be worn by all HCWs working in outpatient settings. In every hospital, the PPE standard should be carefully evaluated by a MDT group including the expert of nosocomial infection control, outpatient management and nurse management, in order to match the situation of different hospitals.

For the high level clinics, we suggest providing medical respirators and medical examination gloves. For the staff associated with respiratory tract examination, medical face screen, and isolation gown should be provided. The normalization of PPE and respiratory tract examination process should attract highly attention.

For the medium level clinics, regarding basic PPE as the prerequisite, we suggest providing medical respirators and face screens according to the COVID-19 pandemic risk in local community. For the clinics ranked high within the medium level, we should focus on the risk factors with high scores, and conduct improvement projects with more supervisions and guidance.

For the low level clinics, we believe that basic PPE can meet the requirement of infection control and prevention, the key point should be the maintenance of low scores in risk factors.
It was a notable fact that the PPE standard we discussed should stand on the basis of normative pre-examination and triage, which can keep patients with fever or highly suspected COVID-19 infection out of outpatient.

\section{Strength and Weakness}

The highlight of our research was that we built a risk assessment model on COVID-19 infection of HCWs in outpatient clinics, we also designed semi-quantitative scoring indicators for each risk factors, and successfully brought the risk assessment to practice. The management strategies we provided can be valuable references for infection prevention to COVID-19.

A weakness of our research was that we did not take the interactive effect among risk factors into consideration, which may provide extra consequences to the risk level grading. We hope this problem could be solved in our next research.

\section{Ethics Statement}

This research was not associated with human or animal subjects, human cell lines or human tissues, and was exempt from ethics approval.

\section{Acknowledgments}

The database searching of our study was approved by the management departments of Xuanwu Hospital Capital Medical University. The accessing to outpatient management database focused on statistical analysis of surveillance data and was not associated with any searching or browsing of individual patient data. We believed there was no threat to the safety of personal information and privacy, and the study had the ability to protect the confidentiality of patient data and to comply with the Declaration of Helsinki.

\section{Funding}

This study was funded by a Scientific Research and Cultivation Program Foundation in Beijing China (No. PG2019018) grant from Beijing Hospitals Authority and Xuanwu Hospital, Capital Medical University.

\section{Disclosure}

The authors report no conflicts of interest in this work.

\section{References}

1. Novel Coronavirus Pneumonia Emergency Response Epidemiology Team. The epidemiological characteristics of an outbreak of 2019 novel coronavirus diseases (COVID-19) in China. Zhonghua Liu Xing Bing Xue Za Zhi. 2020;41:145-151. 
2. Han Y, Yang H. The transmission and diagnosis of 2019 novel coronavirus infection disease (COVID-19): a Chinese perspective. J Med Virol. 2020;92(1):1-6. doi:10.1002/jmv.25749

3. Central People's Government of the People's Republic of China. 14 Key questions and answers. Available from: http://www.gov.cn/xin wen/2020/02/07/content_5475921.htm. Accessed February 7, 2020.

4. Guo Y-R, Cao Q-D, Hong Z-S, et al. The origin, transmission and clinical therapies on coronavirus disease 2019 (COVID-19) outbreak - an update on the status. Mil Med Res. 2020;7(1):11. doi:10.1186/s40779-020-00240-0

5. Wang D, Bo H, Chang $\mathrm{H}$, et al. Clinical characteristics of 138 hospitalized patients with 2019 novel coronavirus-infected pneumonia in Wuhan, China. AMA. 2020;323(11):1061-1069. doi:10.1001/ jama.2020.1585

6. Qiao F, Huang W, Zong Z, Yin W. Infection prevention and control in outpatient settings in China - structure, resources, and basic practices. Am J Infect Control. 2018;46(7):802-807. doi:10.1016/j.ajic.20 17.12.006

7. Zou L, Ruan F, Huang M, et al. SARS-CoV-2 viral load in upper respiratory specimens of infected patients. $N$ Engl $J$ Med. 2020:2001737. doi:10.1056/NEJMc2001737.

8. Branch-Elliman W, Savor Price C, McGeer A, et al. Protecting the frontline: designing an infection prevention platform for preventing emerging respiratory viral illnesses in healthcare personnel. Infect Control Hosp Epidemiol. 2015;36(3):336-345. doi:10.1017/ice.2014.52

9. Radin JM, Hawksworth AW, Peter E. Epidemiology of pathogen-specific respiratory infections among three US populations. PLoS One. 2014;9(12):e114871. doi:10.1371/journal. pone. 0114871 .

10. Parmeggiani $C$, Abbate R, Marinelli $P$, et al. Healthcare workers and health care-associated infections: knowledge, attitudes, and behavior in emergency departments in Italy. BMC Infect Dis. 2010;10(1):35. doi:10.1186/1471-2334-10-35.

11. Teherán AA, Ramos GC, Prado de la Guardia R. Epidemiological characterization of asymptomatic carriers of COVID-19 in Colombia: a cross-sectional study. BMJ Open. 2020;10(12):e042122. doi:10.11 36/bmjopen-2020-042122

12. Shohini Mukerji C, MacIntyre R, Seale H. Cost-effectiveness analysis of N95 respirators and medical masks to protect healthcare workers in China from respiratory infections. BMC Infect Dis. 2017;17 (1):464. doi:10.1186/s12879-017-2564-9

13. Cook TM. Personal protective equipment during the coronavirus disease (COVID) 2019 pandemic - a narrative review. Anaesthesia. 2020;75(7):920-992. doi:10.1111/anae.15071

14. Youhua CHEN. Application and research progress in risk assessment of nosocomial. Chin Health Standard Manag. 2018;9(9):141.

15. Liu-yi L, Yan XU. Risk assessment of management of healthcare-associated infections. Chin J Infect Control. 2016;15 (7):441-446.

16. Nah K, Mizumoto K, Miyamatsu Y, Yasuda Y, Kinoshita R, Nishiura $\mathrm{H}$. Estimating risks of importation and local transmission of Zika virus infection. PeerJ. 2016;4:e1904. doi:10.7717/peerj.1904

17. Xing L, Liu T, Lin L, et al. Application of the analytic hierarchy approach to the risk assessment of Zika virus disease transmission in Guangdong Province, China. BMC Infect Dis. 2017;17(1):65. doi:10.1186/s12879-016-2170-2

18. Saaty TL. Decision Making for Leaders: The Analytic Hierarchy Process for Decisions in Complex World. Pittsburgh: RWS Publications; 2001.

19. Kardi T. Analytic hierarchy process (AHP) tutorial. Available from: http://people.revoledu.com/kardi/tutorial/AHP/PairedComparison. htm. Accessed February 11, 2021.

20. Chunyu T, Fang Y, Huang Z, et al. Application of the analytic hierarchy process to a risk assessment of emerging infectious diseases in Shaoxing City in Southern China. Jpn J Infect Dis. 2014;67:417-422. doi:10.7883/yoken.67.417
21. Liu W, Guo T, Haoxue L, et al. Healthcare-associated infection prevention and control management in a tertiary hospital and an overall evaluation. Ann Palliat Med. 2020;9(4):1536-1544. doi:10. 21037/apm-20-65

22. Van Buynder P, Konrad S, Kersteins F, et al. Healthcare worker influenza immunization vaccinate or mask policy: strategies for cost effective implementation and subsequent reductions in staff absenteeism due to illness. Vaccine. 2015;33(13):1625e8. doi:10.1016/j. vaccine.2015.01.048

23. Jiang W, Fujie X, Zhou W. Risk factors for SARS among persons without known contact with SARS patients, Beijing, China. Emerg Infect Dis. 2004;10(2):210-216. doi:10.3201/eid1002.030730

24. Qiang F. The data set of nosocomial infection surveillance and the guideline of quality control indicators. National Institute of Hospital Administration(NIHA); 2016:294.

25. Liu W, Yang Y, Jiao Y, et al. Evaluation of the effects of applying the ventricular care bundle (VCB) method for reducing ventilator-associated pneumonia (VAP) in the intensive care unit of a general Chinese tertiary hospital. Ann Palliat Med. 2020;apm-20-289.

26. Peabody JW, Luck J, Glassman P, et al. Comparison of vignettes, standardized patients, and chart abstraction: a prospective validation study of 3 methods for measuring quality. JAMA. 2000;283 (13):1715-1722. doi:10.1001/jama.283.13.1715

27. Zabar S, Hanley K, Stevens D, et al. Unannounced standardized patients: a promising method of assessing patient-centered care in your health care system. BMC Health Serv Res. 2014;5(14):157. doi:10.1186/1472-6963-14-157

28. Luck J, Peabody JW, Dresselhaus TR, et al. How well does chart abstraction measure quality? A prospective comparison of standardized patients with the medical record. Am J Med. 2000;108 (8):642-649. doi:10.1016/S0002-9343(00)00363-6

29. Krane NK, Anderson D, Lazarus CJ, et al. Physician practice behavior and practice guidelines: using unannounced standardized patients to gather data. J Gen Intern Med. 2009;24(1):53-56. doi:10.1007/s11606-008-0826-3

30. Fiscella K, Franks P, Srinivasan M, et al. Ratings of physician communication by real and standardized patients. Ann Fam Med. 2007;5(2):151-158. doi:10.1370/afm.643

31. Martos-Cabrera MB, Mota-Romero E, Martos-García R. Hand hygiene teaching strategies among nursing staff: a systematic review. Int J Environ Res Public Health. 2019;16(17):3039. doi:10. 3390/ijerph16173039

32. Tran K, Cimon K, Severn M, et al. Aerosol generating procedures and risk of transmission of acute respiratory infections to healthcare workers: a systematic review. PLoS One. 2012;7(4):e35797. doi:10. 1371/journal.pone.0035797

33. Macintyre CR, Seale H, Yang P, et al. Quantifying the risk of respiratory infection in healthcare workers performing high-risk procedures. Epidemiol Infect. 2014;142(9):1802-1808. doi:10.1017/ S095026881300304X

34. Ippolito M, Vitale F, Accurso G, et al. Medical masks and respirators for the protection of healthcare workers from SARS-CoV-2 and other viruses. Pulmonology. 2020;26(4):204-212. doi:10.1016/j.pulmoe.20 20.04.009

35. Aydin M, Evrendilek F, Savas SA, Aydin IE, Evrendilek DE. Falling dynamics of SARS-CoV-2 as a function of respiratory droplet size and human height. J Med Biol Eng. 2020;1-7. doi:10.1007/s40846020-00575-y.

36. Wang F-D, Chen -Y-Y, Lee Y-M, et al. Positive rate of serum SARS-CoV immunoglobulin G antibody among healthcare workers. Scand J Infect Dis. 2007;39(2):152-156. doi:10.1080/0036554060 0951226

37. Ran L, Chen X, Wang Y, et al. Risk factors of healthcare workers with corona virus disease 2019: a retrospective cohort study in a designated hospital of Wuhan in China. Clin Infect Dis. 2020;71 (16):2218-2221. doi:10.1093/cid/ciaa287 
38. Hobbs CV, Martin LM, Kim SS, et al. Factors associated with positive SARS-CoV-2 test results in outpatient health facilities and emergency departments among children and adolescents aged $<8$ years Mississippi, September-November 2020. MMWR Morb Mortal Wkly Rep. 2020;69(50):1925-1929. doi:10.15585/mmwr.mm6950e3

39. Wang Q, Wang $\mathrm{X}$, Lin $\mathrm{H}$, et al. The role of triage in the prevention and control of COVID-19. Infect Control Hosp Epidemiol. 2020;41 (7):772-776. doi:10.1017/ice.2020.185

40. Yen MY, Lin YE, Lee CH, et al. Taiwan's traffic control bundle and the elimination of nosocomial severe acute respiratory syndrome among healthcare workers. J Hosp Infect. 2011;77(4):332-337. doi:10.1016/j.jhin.2010.12.002

41. Satheesan MK, Mui KW. A numerical study of ventilation strategies for infection risk mitigation in general inpatient wards. Build Simul. 2020;22:1-10.

42. Cheng VC-C, Wong S-C, Chan VW-M. Air and environmental sampling for SARS-CoV-2 around hospitalized patients with coronavirus disease 2019 (COVID-19). Infect Control Hosp Epidemiol. 2020;41 (11):1258-1265. doi:10.1017/ice.2020.282.

43. World Health Organization (WHO). WHO Housing and Health Guidelines. 2018.

44. Tianxiang YL, Zheng S. Evaluation of disinfection procedures in a designated hospital for COVID-19. Am J Infect Control. 2020. doi:10.1016/j.ajic. 2020.08 .028
45. Guo X, Wang J, Dong H, et al. Survey of COVID-19 disease among orthopaedic surgeons in Wuhan, People's Republic of China. J Bone Joint Surg Am. 2020;102(10):847-854. doi:10.2106/JBJS.20.00417

46. Kamate SK, Sharma S, Thakar S. Assessing knowledge, attitudes and practices of dental practitioners regarding the COVID-19 pandemic: a multinational study. Dent Med Probl. 2020;57(1):11-17. doi:10. $17219 / \mathrm{dmp} / 119743$

47. World Health Organization (WHO). Infection Prevention and Control of Epidemic- and Pandemic-Prone Acute Respiratory Infections in Health Care WHO Guideline. 2014.

48. Offeddu V, Yung CF, Low MSF, Tam CC. Effectiveness of masks and respirators against respiratory infections in healthcare workers: a systematic review and meta-analysis. Clin Infect Dis. 2017;65 (11):1934-1942. doi:10.1093/cid/cix681

49. Demicheli V, Jefferson T, Ferroni E. Vaccines for preventing influenza in healthy adults. Cochrane Database Syst Rev. 2018;2(2) CD001269. doi:10.1002/14651858

50. Huang Z, Zhao S, Li Z. The Battle Against Coronavirus Disease 2019 (COVID-19): emergency management and infection control in a radiology department. J Am Coll Radiol. 2020;17(6):710-716. doi:10.1016/j.jacr.2020.03.011
Risk Management and Healthcare Policy

\section{Publish your work in this journal}

Risk Management and Healthcare Policy is an international, peerreviewed, open access journal focusing on all aspects of public health, policy, and preventative measures to promote good health and improve morbidity and mortality in the population. The journal welcomes submitted papers covering original research, basic science, clinical \& epidemiological studies, reviews and evaluations,

\section{Dovepress}

guidelines, expert opinion and commentary, case reports and extended reports. The manuscript management system is completely online and includes a very quick and fair peer-review system, which is all easy to use. Visit http://www.dovepress.com/testimonials.php to read real quotes from published authors. 